Article

\title{
Rural Governance against Eucalyptus Expansion in Galicia (NW Iberian Peninsula)
}

\author{
Diego Cidrás* $*$, Rubén-Camilo Lois-González and Valerià Paül \\ Department of Geography, University of Santiago de Compostela, Praza da Universidade 1, \\ 15703 Santiago de Compostela, Galicia, Spain; rubencamilo.lois@usc.es (R.-C.L.-G.); v.paul.carril@usc.es (V.P.) \\ * Correspondence: diego.cidras.fernandez@usc.es; Tel.: +34-660125819
}

Received: 31 July 2018; Accepted: 18 September 2018; Published: 24 September 2018

\begin{abstract}
Researchers, planners, and decision makers admit the need to take into account the social conflicts inherent to invasive species management in order to minimize controversy. These conflicts are mainly based on differences in values systems, thus causing antithetical policies in environmental management. On the topic of Eucalyptus plantations, this paper studies two cases in Galicia, a region under an emerging social fight between advocates and opponents: firstly, we analyze a local community that is progressively eradicating Eucalyptus through the principles of ecological restoration; and secondly, a planning initiative led by a local government with a common goal. In order to set the spatial and social dimensions of the conflict, the methodological approach is based on the components of cognitive hierarchy theory and risk perception theory. The results are discussed with the purpose of examining to what extent the case studies imply a new model of rural governance, and in this respect, are transferrable to other situations. We conclude that institutional non-interference in Eucalyptus management facilitates the emergence of diverse new governance practices in the local scale but endures the conflict in its regional dimension.
\end{abstract}

Keywords: invasive species; rural governance; ecological restoration; cognitive hierarchy theory; risk perception

\section{Introduction}

The progressive rhetorical change from government to governance implies a significant degree of public sector restructuring [1]. Basically, governance means a multi-scalar and multi-sector network way of governing that is shared by a myriad of actors [2,3] that tends to conceal the role of the public sector [4,5]. However, the idea of governance is ambiguous [6]. In particular, neoliberalism has associated notions such as efficiency, professionalization, and privatization to governance [7], resulting in multiple actors providing public services [8]. However, this has not implied accepting pluralism as a positive value, leading towards the emergence of conflicts, namely, in rural areas [9].

This paper explores new models of governance against land-use conflict in rural areas regarding the topic of invasive species management. We underline the implications of neoliberalism both from the causes of the problem - expansion of invasive species through forestry plantations-and the roots of the solution - the emergence of nongovernmental management models. We aim to explore how and to what extent the case-studies may imply models of rural governance. Additionally, we also aim to answer how and to what extent the lack of public control facilitates these new models of rural governance.

The conflict around Eucalyptus expansion will constitute the basis of our study. According to IUCN criteria [10] and the latest Spanish public environmental agency verdict [11], these species have invasive characteristics. While this issue is still an open debate today, some institutions, such as the European Union [12], do not recognize its invasive character, and several authors have proven its 
dispersal ability in the Iberian context [13-15]. Nevertheless, our use of the terms 'expansive' and 'invasive' aims to move away from the biological debate and refer, in line with Soto [16], to the social dimension of its expansion and to the associated conflicting scenarios, which are essentially linked to a lack of forestry management, to a progressive abandonment of rural areas, and to the increasing polarization between Eucalyptus advocates and opponents [16].

We argue that Galicia (NW Spain) today represents an emerging scenario of alternative rural governance models to Eucalyptus-based forest policy. Similar to other areas in Southern Europe, Eucalyptus expansion started in Galicia in the mid-20th century and has been accentuated in the last few decades (27,639 hectares in 1973 and 287,983 hectares in 2009). The massive exploitation of this tree is mainly prompted by the major Spanish pulp company, ENCE, which operates in almost half of the Galician local government areas [17]. Beyond the interests of this company, policies led by the Spanish Franco regime (1939-1975) and the Galician Government (devolved in the early 1980s) have boosted this forestry model through the acceptance of Eucalyptus expansion. Today, ENCE exclusively consumes Eucalyptus trees, essentially planted by individual and collective landowners in Galicia (99.91\%) [17]. In this context, social and political anti-Eucalyptus sectors are contesting the widespread policies by promoting governance practices that aim to reduce its expansion. Hence, the object of this paper.

In particular, two case studies representing alternative movements from dominant nongovernmental and governmental models are analyzed. Firstly, a rural community progressively eradicating Eucalyptus through the principles of ecological restoration. Secondly, an anti-Eucalyptus local planning scheme located in a peri-urban municipality. Prior to analyzing the results of these two case studies, the next theoretical section expounds the new rural governance models, namely those that tend to be associated with invasive species management.

\section{Towards a New Conflict Resolution Policy through Pluralism and Restoration}

Rural areas have recently been the setting of emerging bottom-up models in terms of governance, namely in the European Union $[18,19]$. Within these new ways of governing, public policies have frequently underlined the need of making local groups' voices heard in development from below [20], thus empowering civil society to unprecedented levels in rural decision-making. Consequently, rural areas have shifted from direct control of the State into diverse multilevel public-private partnerships, somehow shaped by the ongoing neoliberal model [21]. In fact, the "projectification" of rural Europe has been widely discussed in the last few years [22-25], whereas structural implications arising from the replacement of government presence have often been left out of the discussion [26]. Another key issue under revision is the assumption of value plurality by decision makers in rural governance [16,27]. According to Chambers ([28], pp. 44-45), pluralism aspires to seek "enlightenment in both poles of contrary views, in practice seeing error less in what people say than in their condemnation of what others say", and when applied to rural development, "it demands straddling between social questions of political economy and the material questions of physical ecology".

Under the new rural governance, pluralistic perspectives have seldom been assumed by decision makers [16]. This brings us to the issue of value (in) commensurability. On the one hand, monistic approaches have adopted, inspired by utilitarianism, the commensurability of value [29]. Thus, without making any difference between wants and values [30], monism has always followed the path of utilitarianism by omitting every subjective and critical appraisal of the issue of concern [31]. On the other hand, pluralistic perspectives adopt values open to criticism and reconfiguration [32,33]. Therefore, this approach assumes that value conflict can be solved by deliberation. For instance, in terms of environmental management, value pluralism is assumed to be key to integrate people's relationship with the environment [34,35]. Similarly, UNESCO [36] has considered the integration of local knowledge that is fundamental to achieving proper dynamics in public participation.

When applied to the governance of invasive species, pluralistic perspectives are, in theory, more associated to ecological restoration projects rather than to invasive species management [37]. 
While both approaches share a common goal-restoring ecosystems-they diverge when conveyed to the public. According to Gobster ([38] p. 1), "this difference relates to the use of fear (in invasive species management) as a mechanism for gaining public support and motivating behavioral change". Rather, ecological restoration focuses on the regeneration and balance of ecosystem services in order to achieve sustainability in its three dimensions: ecological, cultural, and economic [39]. This implies, in theory, an integration of cultural values and local knowledge as part of the ecosystem [40]. However, Benayas et al. [41] showed that in practice, most of the projects do not include cultural services in their analysis. This dysfunction can generate, according to Ruoso et al. [42], a misunderstanding of the ecosystem needs, and therefore, of the landscape. In other words, investigation and communication of local perceptions of restoration benefits facilitates consensus building [43]. Additionally, ecological restoration adopts culture as a key element of sustainable development. Therefore, this practice is aligned with other strategic activities associated with sustainable development, such as watershed protection or the defense of the rural quality of life [44].

In order to achieve higher levels of public support, restorationists propose reframing invasive species management strategies within a broader values framework. For instance, some authors have observed at this stage benefits when stressing the values of balance and diversity over the need for eradicating aliens [45]. Similarly, focusing on the positive values and activities of restoration itself has helped other managers solve their conflicts [38]. At this point, it is key to understand that human values towards nature and its management are always affected by psychological, cultural, and evolutionary factors $[46,47]$. In the next section, a methodological framework to study the drivers of these factors is proposed. This framework will allow for a better interpretation of the analyzed case studies.

\section{Methodological Considerations}

\subsection{Methodological Underpinnings}

Two case studies were analyzed, following Estévez et al.'s [48] case-studies, through the components of cognitive hierarchy theory (CHT) and risk perception theory (Figure 1). CHT constitutes a conceptual framework that organizes human behavior in three levels: values, attitudes, and behavior [48-50]. The CHT structure is firstly constituted by one upper and central category integrated by values that form the basis for personal beliefs. In a second level, attitudes define social constructs based on people's beliefs [49]. Thirdly, behavior constitutes the intention of action, influenced by attitudes [51].

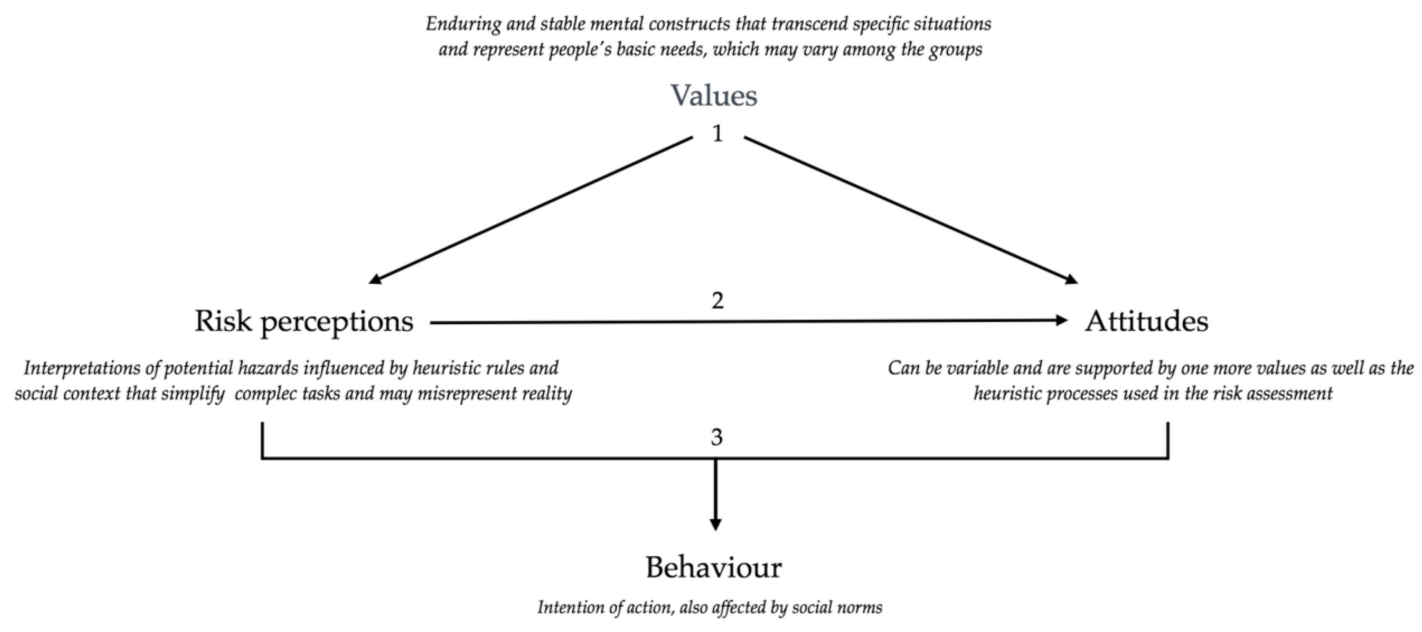

Figure 1. A conceptual framework that integrates cognitive hierarchy theory $(\mathrm{CHT})$ and risk perception theories. Source: Estévez et al. [48] and Zengeya et al. [52]. 
Public decisions are intrinsically determined by individual and collective values [53]. In this context, values can be defined as fundamental beliefs that influence attitudes and guide daily behavior [51]. In terms of invasive species management, social scientists and social scientists have progressively found that core principles and cognitive structures define human behavior [54]. Furthermore, within public decision-making, values may conflict in different ways [31]. Thus, the plurality of values constitutes a potential source of conflict which could vary depending on the scale of analysis [55]. In this article, Kellert's [56] classification of human values on nature is adopted in order to identify the typology or typologies of value of case studies (Table 1).

Table 1. Typology of values of nature. Source: Kellert [56].

\begin{tabular}{|c|c|c|}
\hline Value & Definition & Function \\
\hline Aesthetic & Physical attraction and appeal of nature & Harmony, security, creativity \\
\hline Dominionistic & Mastery and control over nature & $\begin{array}{c}\text { Physical prowess, self-confidence, } \\
\text { mastery skills }\end{array}$ \\
\hline Humanistic & Emotional control over nature & Bonding, cooperation, companionship \\
\hline Naturalistic & Exploration and discovery of nature & Order, meaning, connection \\
\hline Moralistic & Moral and spiritual relation to nature & Curiosity, exploitation, discovery \\
\hline Negativistic & Fear and aversion of nature & Safety, protection, awe \\
\hline Scientific & Systematic and empirical study of nature & $\begin{array}{c}\text { Knowledge, understanding, critical } \\
\text { thinking skills }\end{array}$ \\
\hline Symbolic & Nature in language and expressive thought & $\begin{array}{c}\text { Communication, mental development, } \\
\text { analytical skills }\end{array}$ \\
\hline Utilitarian & Material and physical exploration of nature & $\begin{array}{c}\text { Physical sustenance, material } \\
\text { productivity, survival skills }\end{array}$ \\
\hline
\end{tabular}

Secondly, CHT is enriched by incorporating another analytical theory not included in the original model, risk perception, which basically is envisaged to understand people's attitudes towards nature and its management [48]. Under this approach, human interpretations of signals about uncertain impacts of events, activities or technologies can be perceived from both direct or indirect experiences [57]. Unlike the more complex processes of CHT, risk perception incorporates heuristically simpler mental strategies influenced by common mental mechanisms, frequently fears or the lack of trust of someone or something [58]. In environmental management scenarios, risk-perception-based conflicts usually share fundamental values within the actors of a given conflict [48]. This makes managers' communication of risk key in order to not only understand people's fears but also to solve conflicts based on this source of divisiveness [59]. However, integrating perceptions of fear to environmental management policies can also be a delicate issue. For instance, by analyzing diverse invasive species conflicts, Gobster [38] has proven that fear-based environmental management tends to be less efficient than other less alarming management approaches.

\subsection{Study Areas}

The two case-study areas were in the Western half of Galicia (Figure 2), where most of the Eucalyptus plantations are located due to climatic conditions-high rainfall and moderate temperatures-that facilitate their growth up to altitudes of $800 \mathrm{~m}$. We aimed to work on areas that have had similar impacts from forestry activity on their economies, following ENCE's registry (see [17]). Additionally, we aimed to select one bottom-up governance practice and one top-down in order to contrast them in the discussion.

Firstly, Froxán Common Woodlands is a communal land of 100 hectares located in the village of Froxán and consists of five houses. It is located in the rural municipality of Lousame (35 inhabitants $/ \mathrm{km}^{2}$ ), which has been in recent times hit by a demographic crisis $(-30 \%$ inhabitants since 1985), caused by the collapse of the dairy industry. In 1977, Froxán was recognized under the Galician and Spanish legislation as a "common hand community land"—a collective property regime-in accordance with an ancient consuetudinary land ownership. Before this recent landmark, this area had been incorporated in the late 1920s into the Public Woodlands Catalogue despite the 
purchase of the lands by the peasants during the redemption of manorial rights. Consequently, the traditional rights of use were very restricted during the 20th century, namely, pastoralism, and lands were also handed over to mining companies. Invasive forest species, including Eucalyptus sp. were also introduced in this period. In 2002, the last remaining ties with the Government were broken; thus, the community gained full self-government over the lands. In recent years, the community has been very active in developing restoration activities on their land, in particular Roga e Albaroque-a collective project which combines volunteer work with informal feasts and diverse festive activities in exchange. Through the collaboration of supra-local environmental NGOs, Froxán's Roga e Albaroque transcended the local scale and has turned nowadays into a Galician-wide initiative that will be latterly explained. Additionally, in 2017, Froxán was included in the ICCA Registry [60], being the first area in Southern Europe, together with Santiago de Covelo, to gain this distinction.

The second case study is located less than $30 \mathrm{~km}$ to the NE of Froxán. Ames is a peri-urban municipality that, in contrast to the reality described above, has had strong demographic growth since the late 1980s $(10,011$ inhabitants in 1991; 30,835 in 2017), in the context of the metropolitan area of Santiago de Compostela. Beyond the growth of its two main compact towns (Bertamiráns and $\mathrm{O}$ Milladoiro), urban sprawl in forest/agricultural land cover has been progressively developed. This, combined with the expansion of Eucalyptus sp. and Pinus sp. plantations, caused many wildfires in recent years, namely, in 2006 [61]. This issue has been especially traumatic in the northern half of the municipality, which still conserves strong ties with its rural identity. In response to this crisis, the Local Government has developed a scheme centered on preventing wildfires, including the goal of clearing fire safety strips along public roads and around dwellings.

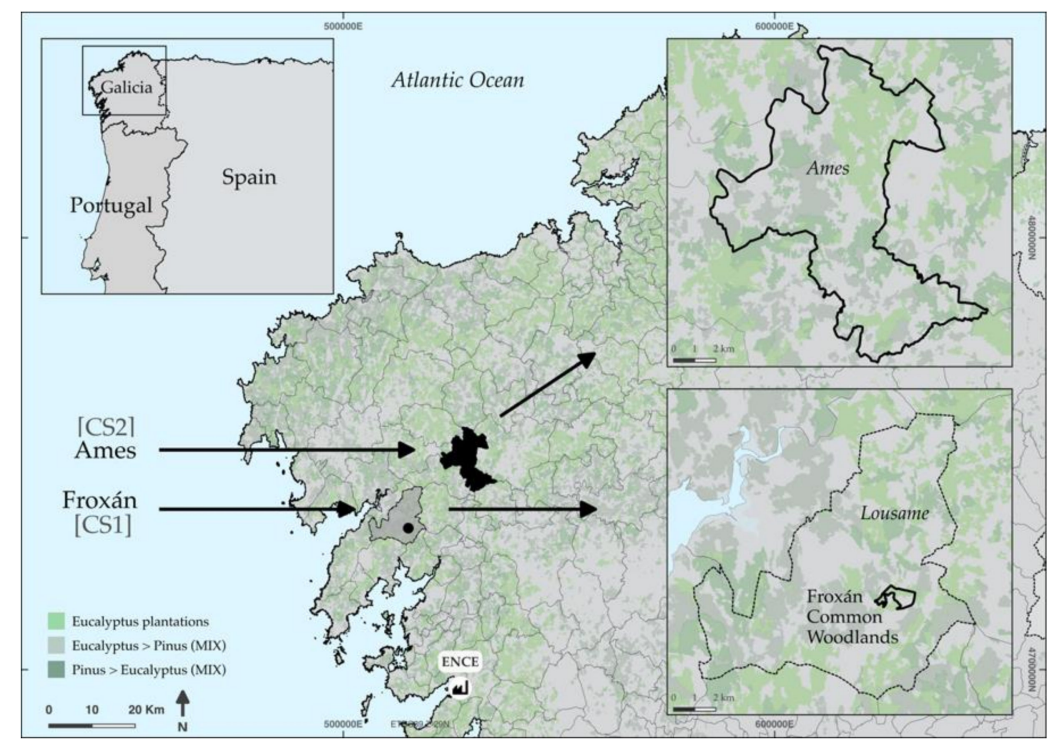

Figure 2. Location of the case-study areas.

\subsection{Materials}

Ten in-depth and semi-structured interviews were carried out with participants, for whom pseudonyms are used throughout the text, following an equivalent distribution of interviewee profiles between both cases. Firstly, in the village of Froxán, we talked to Davide, a neighbor and member of the Froxán Commons; Xoana, a neighbor and member of a cultural association; Iago, a neighbor of a close village in the same parish; Edelmiro, a local politician and councilor in Lousame who lives in a different parish; and Antón, an academic and participant through a collaborative project regarding the biodiversity in Froxán who does not live in the area. Secondly, in Ames, we talked to: Paulo, a neighbor, worker for the Local Government, and promoter of the anti-Eucalyptus local planning 
scheme; Xulia, a neighbor and member of diverse cultural and heritage associations; Carlos, a neighbor and landowner with Eucalyptus plantations; Inés, a neighbor detached from agroforestry practices; and Afonso, an environmentalist who does not live in the area but works on the issue of Eucalyptus expansion. The research did not focus on choosing a representative sample, 'but to understand how individual people experience and make sense of their own lives' ([62], p. 111). The interviewees were selected because of their pivotal role in the development of the governance practices under analysis.

The interviews were recorded and later transcribed with interviewees' consent. The interviews were analyzed through an open-coding approach $[63,64]$, which resulted in 78 codes in Froxán's case and 69 in the one of Ames. The results presented in Section 4 of this paper are an abstraction of these codes. Additionally, controlled observation [65] was conducted in order to analyze attitudes, namely those associated with the description of the relationships between civil society and public administration in its different scales.

\section{Results}

\subsection{Froxán: Transforming the Desire for Pragmatism into Bottom-Up Collaborative Scenarios}

The self-government gained in 2002 by Froxán Commons meant full control over its forestry land. When discussing recent Eucalyptus expansion in the area, those interviewees more distant to Froxán Commons focused on the barriers with the Regional Government, which delivers policy making for forestry management in Galicia. A different perspective was provided inside Froxán Community, which promotes territorial sovereignty through a localist and communalist way of working in order to deal with the Eucalyptus issue. Their claim for change is materialized in a shared attitude within all the local participants: the hope for pragmatism.

This goal has recently been aimed at Froxán through different territorial scales. In 2015, Froxán stood a collective candidature in the local elections in representation of the Partido da Terra (PT) ('Land's Party'), which gained, in the Lousame Local Government, its first councilor ever in Galicia. This green party, which promotes direct democracy and encompasses sovereignty in its diverse perspectives (citizen, territorial, cultural, economic, etc.) faces, in Lousame, the challenge of joining a Local Government where the right-wing Partido Popular (PP) ('Popular Party') obtains majority election after election. Davide takes part in the rotating presidency of the local PT and assumes for one year its representation as a councilor, but he explains that "that experience, compared to the others, was very ... very useless [ ... ] it wasn't worth it to continue feeding the animal". Consequently, the PT members in Lousame, Davide among them, agree to bring their efforts back to their respective villages.

Back to Froxán, in 2016, the community started being more active in engaging the wider society in the Eucalyptus issue. Xoana stated that "Only one person per house integrates Froxán Commons [ ... ] so, the rest, we didn't really take part in it ... then, we tried to find out an alternative way of collaborating". This hope for collective efficiency motivated her to promote the Coluna Sanfins association, "which is quite diverse. We deal with education, with recreational approach [ ... ] what we really look for is the implication of the people in our territory". In parallel, collaboration efforts in Froxán started to transcend the local scale in order to gain external support: "Froxán Commons, hand in hand with Coluna Sanfins ... we worked together, [ ... ] and connected with some external entities, such as Verdegaia and ADEGA [Galician-wide environmental NGOs] we help each other, we try to be reciprocal".

Through this new collaborative scenario, different types of restoration activities were developed in a short period of time in Froxán. One of them ended up being relevant in social terms. This is the case of Roga e Albaroque, an adaptation of an ancestral practice that consists of a restoration group work (the Roga), commonly performed over the weekend, in exchange for an after-work feast for the volunteers (the Albaroque). The activity therefore focuses on restoring native forests in areas that had been occupied by Eucalyptus (Figure 3a,b). In preparation for the Rogas, the members of Froxán Commons agree on the areas of intervention for the restoration activity in their communal lands. 
The success of the activity in terms of participation motivated supra-local environmental associations to create, in collaboration with Froxán Community, an equivalent project to the Roga e Albaroque which could be applied in different areas in Galicia. In the words of Davide, "it's like a subproduct, like a spin-off of what we started doing here". At the time of writing these words, this new supra-local project, named Brigadas Deseucaliptizadoras ('Anti-Eucalyptus Brigades'), is still under development.

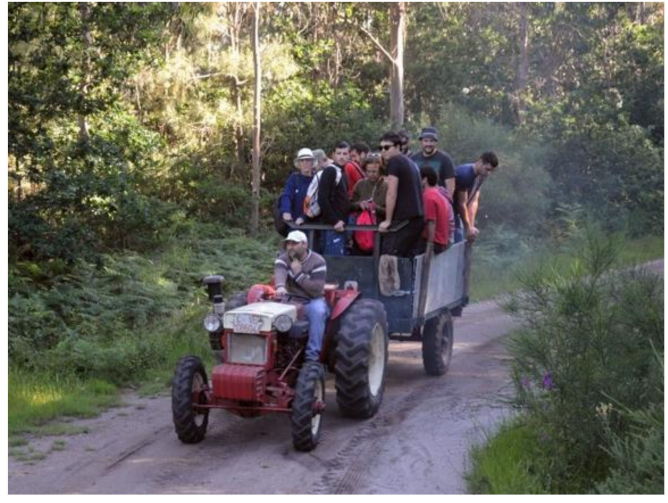

(a)

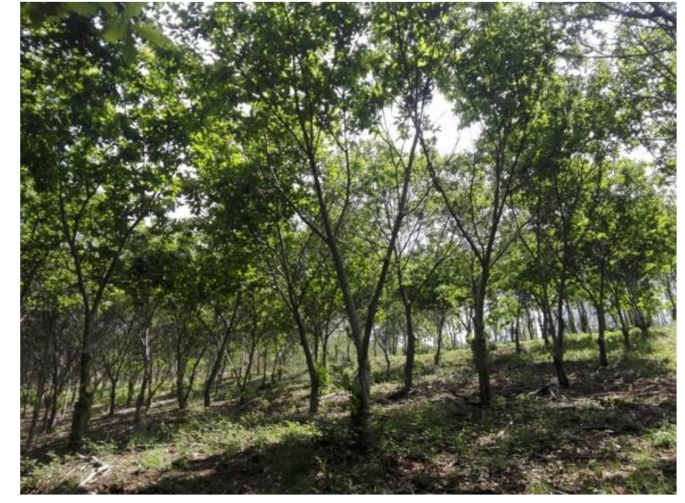

(b)

Figure 3. (a) Participants of a Roga e Albaroque getting ready for the Roga. Picture by Verdegaia NGO; and (b) Restored oak forest in Froxán. Picture by Diego Cidrás.

\subsubsection{The Approximation between Froxán Community and External Participants}

Through diverse social networks and the support of external environmental associations, Froxán Commons immediately recruited participants from urban areas: "most of the people", stated Xoana, "I'd say that they respond to an urban profile. People between 20, 40 years ... people who haven't had contact with forestry management before". During the debates about the diverse activities Froxán formulates against Eucalyptus expansion, we identified three fundamental aspects that provide shared meaning to their projects:

- The importance given to the role of space.

- The strong belief in the power of community.

- A strategic encouragement for participation.

The concept of space comes up when all of our interviews deal with issues associated with depopulation and related conflicts. "We're riddled in so many ways. You know, the topic: the desire of exploiting resources ... our land" (Xoana). Therefore, as "rural vacant land is a temptation for thieves" (Davide), it is "fundamental to be here, in touch with the land ... I try so." (Iago). Against that lack of defense, "you can have an NGO with an office there, with volunteers wherever, a group of parachutes ... but it's never equivalent to this". Legitimacy is deeply conditioned by the villagers of Froxán to the fact of conserving autonomous leadership: "otherwise, it will never be a legitimate fight, since you are not based on the area. It will never be as efficient as ... when people live there, see what's going on ... " (Davide).

Secondly, the ideas of agreement and, in a broader sense, community converge in all of the discourses as an essential condition to materialize their projects. The reconstitution of Froxán Commons provides each of the houses in the village with one vote to take communal decisions over land management. Different from most of the communal woodlands in Galicia, "in Froxán we don't have a governing board. We take all our decisions in assemblies" (Davide). Still, in some ways, this scenario is not perceived as open enough by the villagers: "That's why we constituted the Coluna Sanfins. We wanted to make it just more open; to go further ..." (Xoana). This scenario fits in both Antón and Edelmiro's understanding of Froxán's restoration activities, since they describe "those villages up there" as "considerably ... very alive and participative" (Antón). 
Thirdly, we highlight Froxán's strategic encouragement of civil participation in restoration projects. When announced, this call tends to be associated with the issue of Eucalyptus expansion due to its call effect, whether the announced activity deals with the eradication of Eucalyptus or not:

"Social perception about Eucalyptus is changing [ ... ] society ... it's getting more critical, namely in urban areas ... which are the most relevant in electoral terms. [ ... ] Sometimes, maximalist perspectives-with regard to how the Anti-Eucalyptus Brigades had been denominated-are necessary" (Antón).

\subsubsection{An Accepted Estrangement with the Regional Government}

We identify a general perception that the Xunta—the Galician Regional Government—promotes Eucalyptus expansion through a conniving relationship with the pulp industry, ENCE. This is associated by all the anti-Eucalyptus interviewees with abstract economic interests that the Xunta has in forestry policy. Further, Xoana argues that the Galician Government aims to obstruct the autonomous development of communal woodlands, since "historically, they have been a huge barrier to us [ ... ] whenever we try to do something new, we find Xunta's barrier". Consequently, Froxán's estrangement with the Xunta is held by the idea that the government discredits not only communal lands themselves, but also their particular activities.

These perceptions perpetuate their desire for autonomy. When reflecting on the existing relationship between current restoration projects with the Government, only Davide assumed that despite "our projects, today ... do not have any relationship with the Xunta". In the future "there's potential to do this from Local Government, even the Xunta". Differently, Xoana points that "if they act ... it's going to be in a negative way [ ... ] if they had the tools to block these practices, they would do so".

This ambiguity reflects uncertainties motivated by the omission of the Regional Government in these kinds of activities. This omission is perceived by Davide as "a window". Similarly, Antón identifies "gaps ... for taking some advantage to develop your alternatives". He follows up by arguing that even though the forestry scheme is oriented to favor the company ENCE, "there exists a juridical framework [... ] that facilitates alternatives". However, he advises that these alternatives require knowledge and legal advice, which he finds characteristic of Froxán Community. In fact, the interviewees contribute to the understanding that this village has earned distinction and leadership in some degree due to the particular knowledge acquired by key local actors like Davide.

\subsection{Ames: Regaining Power through Top-Down Governance}

The wildfire crisis in 2006 was the point of departure for this initiative. This crisis essentially affected the Northern half of the municipality, where we can still find the major Pine and Eucalyptus plantations. As a consequence of the crisis, one of the technical departments of the Local Government started working on a scheme centered, a priori, on preventing wildfires. This document was initially called the Plan de Prevención e Defensa contra os Incendios Forestais-PPDIF ('Local Fire Prevention Plan'). Xulia, who took part in the development of the plan, talked about "a try of intervention, planning ... there's an initiative followed by some work done by the government, the local one in this case". This scheme was not implemented until 2016.

The first big narrative reproduced by the interviewees was in fact associated with the philosophy of the PPDIF. They assumed that this document aimed, in between the guidelines against wildfires, to "fight" (Afonso) and "battle" (Xulia) Eucalyptus expansion in the municipality. These species are thereupon tagged by some informants as "damaging" (Afonso) in terms of biodiversity, as well as "very dangerous, since we're talking about a pyrophyte species" (Xulia). Paulo assumed the incorporation of the Eucalyptus issue to their project spontaneously: "We take advantage that there is a normative to take a step forward. I mean, you won't convince the neighbors to take the Eucalyptus away, because they won't get convinced ...." 
Importantly, a Local Government is not responsible for forestry management; however, in through a local land-use planning framework devoted to areas where the Local Government has competences (fire prevention and heritage conservation), forestry management is de facto covered: "We are just making some ... legal friction" (Paulo). With all that, Paulo often remarks about the "limitations of their project", since they can only take action on peri-urban locations: "This is, especially, something that protects our towns ... it's not a solution to Galician forest management. It's about emergency". Similarly, Carlos points out that "basically, what they do is cleaning and generating fire safety strips". In summary, against the Xunta's legislation, the Local Government develops forestry management in order to reduce Eucalyptus extension in the municipality:

"Yeah ... municipalities do not have competences on forestry management. [ .. . ] In theory, we, the municipalities, have the obligation to comply with these obligations [in reference to fire prevention]. Then, we overact ... like the bad actors! We say, c'mon! Is that our obligation? Let's take profit and while we are at it reduce Eucalyptus ... " (Paulo).

Once the fire safety strips were planned, the negotiation process with the affected landowners started in 2016. They offered to cut down pyrophytes species and restore oaks and chestnut trees in the designed safety strips, assuming for the local municipality $100 \%$ of the costs of the plantations and $80 \%$ of their maintenance. Carlos, owner of small plantations in the area, favorably views this protective policy: "Well, people were kind of cheerful, it's better than ... somehow, the fire safety strips ... towards human protection, are fine" (Figure 4a,b) However, he follows up with the point that, besides these $30 \mathrm{~m}$, the logistics change: "If the landowner has a $60 \mathrm{~m}$ width plantation and he gets oaks in the first $30 \mathrm{~m}$, what do you think he'1l do in the other $30 \mathrm{~m}$ : to plant oaks?". Regarding this point, there is a consensus among our interviewees that, on paper, the majority of landowners would maintain Eucalyptus plantations if they were not buffered in the PPDIF.

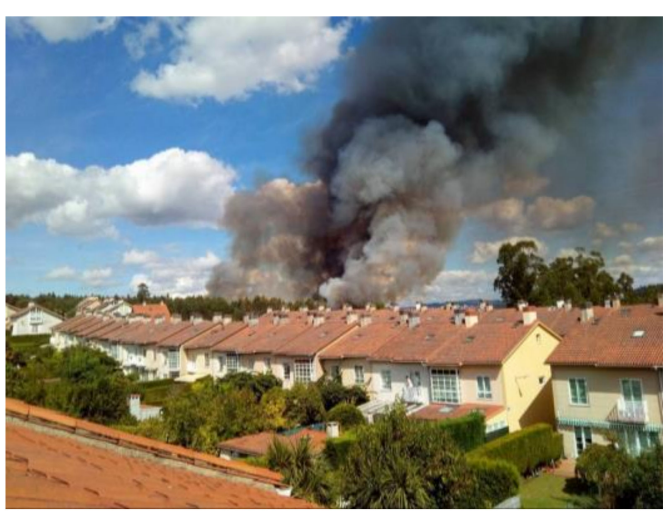

(a)

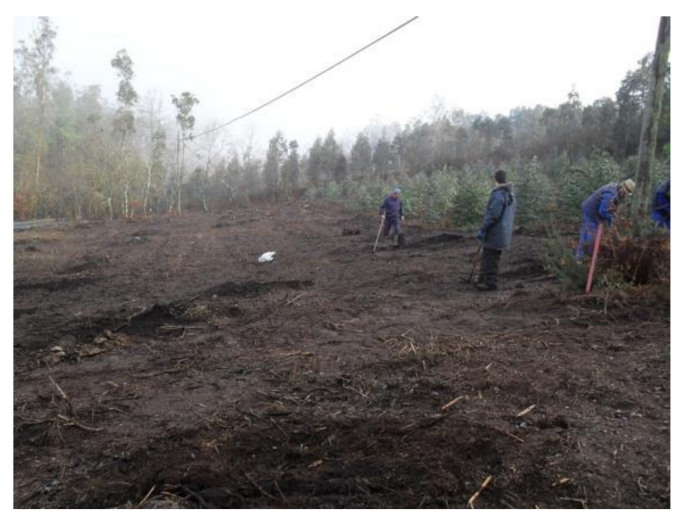

(b)

Figure 4. (a) Wildfire close to a residential area in Aldea Nova (Ames); and (b) Public workers finishing a fire safety strip. Pictures by the Local Government of Ames.

\subsubsection{The Approximation between the Local Government and Neighbors}

According to the interviewees, the dialogue and negotiation processes between the Local Government and the landowners, far from being problematic, emerges as a pivotal milestone of the development of this initiative. The materialization of the PPDIF, namely, its fire safety strips, is perceived by our interviewees as a successful process, essentially with regard to the perceived reconciliation between the Local Government and civil society. This approximation is characterized by three key aspects of the Local Government:

- Their understanding that the landowners tend to prioritize the economic value of their lands.

- Their efforts to visualize the diverse benefits associated with the fire safety strips.

- Their continuing facilitation of information and tools towards alternatives to Eucalyptus plantations. 
This way of approaching the landowners was essentially a premeditated strategy designed in the Local Government, negotiated, and supported by different key actors in the areas where the PPDIF was about to be implemented. For each negotiation, the Local Government organizes panel discussions where they fundamentally provide information to the neighbors. Beyond the issue of the fire safety strips, the Local Government progressively introduces debates about alternative models of forest exploitation among the neighbors. Thus, the administration aims to facilitate information about alternatives to Pinus and Eucalyptus plantations.

"What we [Ames' Local Government] don't understand is that the neighbors are the main interested people to achieve that. What is, then, happening? That we don't provide information! [ ... ] We need to face the neighbors talk to them and explain them the alternatives" (Paulo).

The negotiating process is perceived as consistent, respectful, and supportive by the neighbors. From her external perspective, Inés related that "with regard to that Eucalyptus issue in Piñeiro, I think everything went pretty fine. I didn't hear about any conflict, neither about complaints ... yeah". Similarly, Afonso provided a positive, perhaps idyllic, overview of the process by assuming that "now, with this plan, neighbors will see reason [ ... ] and start working with mushrooms and chestnuts ... ". From a more internal perspective, Carlos explained that besides the fact that the negotiating process seems to be easy and transparent, the landowners tend to accept it essentially due to the good conditions offered by the Local Government in terms of technical advice and economic support.

\subsubsection{An Accepted Estrangement with the Regional Government}

Last, we relate the existing perception of the role adopted by the Regional Government in this case. There exists a general thinking between our interviewees that, despite having legal powers on forest policy-making, the Xunta avoids assuming control of Eucalyptus expansion and any kind of related issue. According to their interpretations, the emergence of cases like the PPDIF of Ames are also ignored, or at least obviated in public. In this sense, Afonso formulates that "while these little things don't transcend much, there will be a laissez-faire. Their typical attitude ... ". Paulo remarks that "the Minister with competences visited us [ ... ] she's even said that this experience seemed to be interesting to her ... beats me!".

This overall discourse is combined with two general critiques of the regional government. They are related to the uncontrolled emergence of illegal plantations on the one hand, and to the deficient management of wildfires on the other. The former is described as causing "the sensation of a lack of public support towards their abolition" (Afonso), and makes them perceive reporting illegal plantations something useless. According to the environmentalists, this demotivation is frequently transformed into fear in rural areas. This is making several individuals attend to environmentalists' offices in order to report an illegal plantation:

"Then, yeah, one of the reasons why people turn to our office is because they know that the Xunta is like hitting a brick wall; they assume that the Xunta promotes Eucalyptus expansion and, on the other hand, they don't really want to have conflicts with landowners [ ... ] in rural areas there exists an omertà with regard Eucalyptus ... no one can rat" (Afonso).

Similar to the critiques towards illegal plantations, the interviewees reproduced in Ames an equivalent discourse on the issue of wildfires associated with Eucalyptus plantations. According to all our interviewees, the Xunta dodges responsibilities and tends to assume wildfires as something "logical" (Xulia) or "politically unavoidable" (Carlos). "They just want to avoid massive wildfire crises because that would have a negative impact on the next elections, you know" (Inés). These perceptions are followed up by the argumentation that there exists an extended traditional but uncontrolled use of fire for diverse land-use management practices. All in all, these diffuse supra-local controversies are a shared belief among all the interviewees involved in the development of the PPDIF. This consensus view facilitates, to a greater or lesser degree, collaboration at the local scale. 


\section{Discussion and Conclusions}

Both studied experiences respond to the concept of governance [3], namely, to its associated weakening of the public sector, as identified by Haslam McKenzie [5] and Paül [4]. In this sense, Eucalyptus expansion motivates at the local scale this kind of governance, which somewhat colludes with the Regional Government and the major pulp industry in the area. This fits in with Nousiainen and Pylkkänen's [21] understanding of governance as a multilevel governing scenario conditioned by the neoliberal agenda, where structural implications-rural development and forestry policy-gained discursive centrality among local actors. Therefore, these experiences also correspond to Arora-Jonsson's [26] critical framework, since they center attention on these conflicting structural issues in order to condemn their abandonment. Consequently, the perceived arrival of neo-liberalism has been a key motivation to the emergence of both governance practices. Taking into consideration the components of $\mathrm{CHT}$ and risk perception theory, several spatial aspects related to this particular rural governance are worth discussing.

Geographical framework plays a transforming role in the emergence of governance practices. Initially, we experienced in our cases opposite understandings of how "rural" was defined and also degraded. Episodes of land grabbing motivated, in Froxán, a higher lack of trust in government institutions, in line with Slovic's findings [57], whereas this phenomenon was not initially reproduced in Ames. Further, the constitution of the spatial scale of these governance practices is, in both cases, essentially limited to the local dimension and has determined their particular values. This links with Trainor's understanding of value frameworks [54], since the intentioned breakup between local actors and the Regional Government responds in Ames and Froxán to a limitation of value plurality. Therefore, although authors like Hothenthal [9] focus on the lack of value pluralism in rural areas due to a dominance of top-down governance practices, we have experienced that this same shortage tends be reproduced also in bottom-up dynamics. However, the aforementioned limitation of actors and value pluralism did not imply a concealing of local knowledge. In fact, following Brancolion's et al. [43] thesis, consensus-building has been achieved in both cases through the integration of local voices in governance practices.

Further, human values towards nature have also constructed different governance frameworks depending on the geographical context [56]. On this matter, we have observed two different patterns regarding the social valuation of Eucalyptus expansion in their respective territories. On the one hand, those groups of actors more self-identified with a rural way of life have followed Kellert's [56] definition of territorial humanistic valuation. Their resulting governance against Eucalyptus expansion has therefore been based on the constitution of new bonding and cooperative scenarios, driven by the desires of pragmatism through an empathic understanding of the territory. On the other hand, those groups of actors more self-identified with a rurban or complete urban way of life have based governance against Eucalyptus on the values of civil security, landscape harmony, and an abstract defense of rurality. This fits with Kellert's [56] identification of aesthetic valuation of the environment. Significantly, despite the extended presence of Pinus trees, commonly in mixture with Eucalyptus, in both study areas, no negative valuations have been reproduced by the interviewees towards the former.

Risk assessment, which has been deeply associated with wildfire proliferation in Ames, constituted the technical and even ideological core of their governance practice. Here, risk perception has not only simplified the Eucalyptus issue into a security-based debate but has also unified positions among the local actors in a complex scenario, as reproduced by Estévez et al. [48]. Additionally, in line with Slovic [58], this phenomenon implied an extended lack of trust among actors or groups of actors, namely in the Regional Government as a whole. This estrangement has also reproduced an internal unification of attitudes within governing actors. Therefore, despite the aforementioned abstraction of value framework, which would lead us to understand to a great extent the resulting behaviors within the materialization of governance [51], the case of Ames brings to light the strong influence that risk assessment has had over the case. 
Consequently, different risk perception and value frameworks ended up producing significantly different governance practices. On the one hand, Froxán's Roga e Albaroque based its participatory framework on stressing the values of diversity and balance, as experienced in Burger et al. [39], and involved several references to cultural values, as suggested by Pueyo-Ros [40], thus being quite unique within recent restoration projects [41]. Therefore, governance against Eucalyptus expansion in Froxán responds to the concept of ecological restoration [37]. On the other hand, Ames' PPDIF sustained public participation on a more legalistic and fear-based participative framework, as seen in Gobster [38]. Initially, this framework would respond to the idea of invasive species management. With all, according to Verweij [37], their integration of value pluralism within the local community, materialized in a socially accepted and approved of negotiation process, brings this practice close to the principles of ecological restoration.

In conclusion, despite extended pessimism due to Eucalyptus expansion in areas like Galicia, there are emerging governance alternatives attempting to revert the process. This paper has studied two experiences in rural areas, one bottom-up and the other top-down, which shared many similarities in terms of ecological restoration. We identified the growing and transforming influence of urban society on rural governance against Eucalyptus. We argue that this process can be conditional to medium-term forestry policy, namely, in abandoned rural areas.

In accordance with Arora-Jonsson [26], we conclude that a laissez-faire governmental attitude in forestry policy motivates the emergence of new models of governance. However, this research shows that these models are spatially isolated, work in limited areas, and are apparently unable to transcend their methods outside their respective piecemeal territories of action. Further studies are needed to grasp how local actors may go beyond their local practices into supra-local scales. This could facilitate the reduction of social polarization on the issue of Eucalyptus management.

Author Contributions: Conceptualization, D.C.; Methodology, D.C. and V.P.; Software, D.C.; Validation, R.-C.L.-G. and V.P.; Formal Analysis, D.C.; Investigation, D.C.; Resources, D.C., R.-C.L.-G. and V.P; Data Curation, D.C.; Writing-Original Draft Preparation, D.C.; Writing-Review \& Editing, R.-C.L.-G. and V.P.; Visualization, D.C.; Supervision, R.-C.L.-G. and V.P.; Project Administration, R.-C.L.-G. and V.P.; Funding Acquisition, D.C., R.-C.L.-G. and V.P.

Funding: This research is supported by the PhD scholarship "Programa de axudas á etapa predoutoral" provided by the Xunta de Galicia (Consellería de Cultura, Educación e Ordenación Universitaria) to D.C. (grant number ED481A-2018/263) and the research grant "Consolidación e estruturación. 2016 GRC GI-1871 Análise territorial" provided by the Xunta de Galicia (Consellería de Cultura, Educación e Ordenamento Universitario) to the ANTE Research Group, directed by R.-C.L.-G. (grant number ED431CR-2016/010).

Acknowledgments: We would like to express our great appreciation to all our interviewees. Also, to Patricia Ares for her valuable help in language editing. Our special thanks are extended to Verdegaia and Froxán's community for their warm welcome and inspiring experiences.

Conflicts of Interest: The authors declare no conflict of interest.

\section{References}

1. Evans, B.; Richmond, T.; Schields, J. Structuring Neoliberal Governance: The Non Profit Sector, Emerging New Models of Control and the Marketisation of Servide Delivery. Policy Soc. 2005, 24, 73-97. [CrossRef]

2. Kickert, W. Compelxity, Governance and Dynamics: Conceptual Explorations of Public Network Management. In Modern Governance; Kooiman, J.M, Ed.; Sage Publications: London, UK, 1993; pp. 191-204.

3. Stoker, G. Governance as Theory: Five propositions. Int. Soc. Sci. J. 1998, 50, 17-28. [CrossRef]

4. Paül, V. Hopes for the Countryside's Future. An Analysis of Two Endogenous Development Experiences in South-Eastern Galicia. J. Urban Reg. Anal. 2013, 5, 169-192.

5. Haslam Mckenzie, F. Delivering Enduring Benefits from a Gas Development: Governance and Planning Challenges in Remote Western Australia. Aust. Geogr. 2013, 44, 341-358. [CrossRef]

6. Böcher, M. Regional Governance and Rural Development in Germany: The Implementation of LEADER+. Sociol. Rural. 2008, 48, 372-388. [CrossRef]

7. Leitner, H.; Sheppard, E. The City Is Dead, Long Live the Net: Harnessing European Enterurban Networks for a Neoliberal Agenda. Antipode 2002, 34, 495-518. [CrossRef] 
8. Bovaird, T. Public Governance: Balancing Stakeholder Power in a Network Society. Int. Rev. Adm. Sci. 2005, 71, 217-228. [CrossRef]

9. Hohenthal, J.M.; Räsänen, M.; Minoia, P. Political Ecology of Asymmetric Ecological Knowledges. Diverging Views on the Eucalyptus-Water Nexus in the Taita Hills, Kenya. J. Political Ecol. 2018, 25, 1-19. [CrossRef]

10. MAPAMA-Ministerio de Agricultura y Pesca, Alimentación y Medio Ambiente. Dictamen del Comité Científico CC 30/2017. Available online: http:/ / www.ibader.gal/archivos/2018-0409-DICTAMEN-EUCAL510.pdf (accessed on 23 August 2018).

11. Davis, M.A.; Thompson, K. Invasion terminology: Should Ecologists Define their Terms Differently than Others? No, Not if We Want to Be of Any Help! Bull. Ecol. Soc. Am. 2001, 82, 206.

12. Official Journal of the European Union: Regulation (EU) No 1143/2014 of The European Parliament and of the Council. Available online: https:/ / eur-lex.europa.eu/legal-content/EN/TXT/?qid=1483614313362\& uri=CELEX:32014R1143 (accessed on 23 August 2018).

13. Blanco-Arias, C. Un plan para controlar las plantas exóticas en las Islas Atlánticas de Galicia. Quercus 2017, 375, 26-30.

14. Teixido, A.; Quintanilla, L.; Carreño, F.; Gutiérrez, D. Impacts of changes in land use and fragmentation patterns on Atlantic coastal forests in northern Spain. For. Ecol. Manag. 2010, 91, 879-886. [CrossRef] [PubMed]

15. Calviño Cancela, M.; Rubido-Bará, M. Invasive Potencial of Eucalyptus Globulus: Seed Dispersal, Seedling Recruitment and Survival in Habitats Surroundings Plantations. For. Ecol. Manag. 2013, 305, 129-137. [CrossRef]

16. Soto-Caba, M.A. Aproximación al origen y naturaleza de la conflictividad de las plantaciones de eucalipto (Eucalyptus ssp.) en España. Congr. For. 2013, 6CFE01-60,1-12.

17. ENCE_Energía y Celulosa. Informe de Impacto Forestal de Ence en Galicia. Available online: www.ence. es/images/pdf/Informe_Economico_Forestal_Ence.pdf (accessed on 12 April 2017).

18. ENRD—European Network for Rural Development. The Implementation of the Bottom-up Approach. Extended Report. Available online: https://enrd.ec.europa.eu/leader/focus-groups/focus-group-1_en (accessed on 9 September 2017).

19. Esparcia, J.; Escribano, J.; Serrano, J.J. From Development to Power Relations and Territorial Governance: Increasing the Leadership Role of LEADER Local Action Groups in Spain. J. Rural Stud. 2015, 42, $29-42$. [CrossRef]

20. Sustainable Development in the European Union: 2017 Edition. Available online: http://ec.europa.eu/ budget/img/budget4results/SustainableDevelopmentInTheEU.pdf (accessed on 5 February 2018).

21. Nousiainen, M.; Pylkkänen, P. Responsible Local Communities-A Neoliberal Regime of Solidarity in Finnish Rural Policy. Geoforum 2013, 48, 73-82. [CrossRef]

22. Marsden, T.; Sonnino, R. Rural Development and the Regional State: Denying Multifunctional Agriculture in the UK. J. Rural Stud. 2008, 24, 422-431. [CrossRef]

23. Kovách, I.; Kučerová, E. The Social Context of Project Proliferation. The Rise of a Project Class. J. Environ. Policy Plan. 2009, 11, 203-221. [CrossRef]

24. Shucksmith, M. Class, Power and Inequality in Rural Areas: Beyond Social Exclusion? Sociol. Rural. 2012, 52, 377-397. [CrossRef]

25. Lukić, A.; Obad, O. New Actors in Rural Development. The LEADER Approach and Projectification in Rural Croatia. Sociologija i prostor: Časopis za istraživanje prostornoga i sociokulturnog razvoja 2016, 54, 71-90.

26. Arora-Jonsson, S. The realm of freedom in new rural governance: Micro-politics of democracy in Sweden. Geoforum 2017, 79, 58-69. [CrossRef]

27. Pahl-Wostl, C. A Conceptual Framework for Analysing Adaptive Capacity and Multi-level Learning Processes in Resource Governance Regimes. Glob. Environ. Chang. 2009, 19, 354-365. [CrossRef]

28. Chambers, R. Rural Development: Putting the Last First; Routledge: London, UK, 2014.

29. O'Neill, J. Ecology Policy and Politics; Routledge and Kegan Paul: London, UK, 1993.

30. Frankfurt, H.M. Freedom of will and the concept of a person. J. Philos. 1971, 68, 5-20. [CrossRef]

31. Costa, A.; Caldas, J.C.; Coelho, R.; Ferreiro, M.D.; Gonçalves, V. The building of a dam: Value conflicts in public decision-making. Environ. Values 2016, 25, 215-234. [CrossRef] 
32. Dewey, J. Human Nature and Conduct. An Introduction to Social Psychology; The Modern Library: New York, NY, USA, 1930.

33. Costa, A.N.; Caldas, J.C. Claiming Choice for Institutional Economics. J. Econ. Issues 2011, 45, 665-684. [CrossRef]

34. Mosse, D. Collective Action, Common Property, and Social Capital in South India: An Anthropological Commentary. Econ. Dev. Cult. Chang. 2006, 54, 695-724. [CrossRef]

35. Walker, G. Beyond Distribution and Proximity: Exploring the Multiple Spatialities of Environmental Justice. Antipode 2009, 41, 614-636. [CrossRef]

36. Indigenous and Local Knowledge(s) and Science(s) for Sustainable Development. Available online: http: / / unesdoc.unesco.org/images/0024/002461/246104E.pdf (accessed on 19 September 2017).

37. Verweij, M. The Remarkable Restoration of the Rhine: Plural Rationalities in Regional Water Politics. Water Int. 2017, 41, 207-221. [CrossRef]

38. Gobster, P.H. Invasive Species as Ecological Threat: Is Restoration an Alternative to Fear-based Resource Management? Ecol. Restor. 2005, 23, 261-270. [CrossRef]

39. Burger, J.; Gochfeld, M.; Pletnikoff, K.; Snigaroff, R.; Snigaroff, D.; Stamm, T. Ecocultural Attributes: Evaluating Ecological Degradation in Terms of Ecological Goods and Services Versus Subsistence and Tribal Values. Risk Anal. Int. J. 2008, 28, 1261-1272. [CrossRef] [PubMed]

40. Pueyo-Ros, J. Serveis ecosistèmics, valors del paisatge i sostenibilitat cultural en projectes de restauració ecològica. Documents d'anàlisi geogràfica 2018, 64, 291-311. [CrossRef]

41. Benayas, J.M.; Newton, A.C.; Diaz, A.; Bullock, J.M. Enhancement of Biodiversity and Ecosystem Services by Ecological Restoration: A meta-analysis. Science 2009, 325, 1121-1124. [CrossRef] [PubMed]

42. Ruoso, L.E.; Plant, R.; Maurel, P.; Dupaquier, C.; Roche, P.K.; Bonin, M. Reading Ecosystem Services at the Local Scale through a Territorial Approach: The case of peri-urban agriculture in the Thau Lagoon, Southern France. Ecol. Soc. 2015, 20, 1-16. [CrossRef]

43. Brancalion, P.H.; Cardozo, I.V.; Camatta, A.; Aronson, J.; Rodrigues, R.R. Cultural Ecosystem Services and Popular Perceptions of the Benefits of an Ecological Restoration Project in the Brazilian Atlantic Forest. Restor. Ecol. 2014, 22, 65-71. [CrossRef]

44. Brancalion, P.H.; van Melis, J. On the Need for Innovation in Ecological Restoration. Ann. Mo. Bot. Gard. 2017, 102, 227-236. [CrossRef]

45. Sauer, L. The Once and Future Forest: A Guide to Forest Restoration Strategies; Island Press: Washington, DC, USA, 1998.

46. Glacken, C.J. Traces on the Rhodian Shore: Nature and Culture in Western Thought from Ancient Times to the End of the Eighteenth Century; University of California Press: Los Angeles, USA, 1967.

47. Kaplan, R.; Kaplan, S. The Experience of Nature: A Psychological Perspective; Cambridge University Press: Cambridge, UK, 1989.

48. Estévez, R.A.; Anderson, C.B.; Pizarro, J.C.; Burgman, M.A. Clarifying values, risk perceptions, and attitudes to resolve or avoid social conflicts in invasive species management. Conserv. Biol. 2015, 29, 19-30. [CrossRef] [PubMed]

49. Fulton, D.C.; Manfredo, M.J.; Lipscomb, J. Wildlife Value Irientations: A Conceptual and Measurement Approach. Hum. Dimens. Wildl. 1996, 1, 24-47. [CrossRef]

50. Whittaker, D.; Vaske, J.J.; Manfredo, M.J. Specificity and the cognitive hierarchy: Value orientations and the acceptability of urban wildlife management actions. Soc. Natl. Resour. 2006, 19, 515-530. [CrossRef]

51. Rokeach, M. The Nature of Human Values; Free press: New York, NY, USA, 1973.

52. Zengeya, T.; Ivey, P.; Woodford, D.J.; Weyl, O.; Novoa, A.; Shackleton, R.; Richardson, D.; van Wilgen, B. Managing conflict-generating invasive species in South Africa: Challenges and trade-offs. Bothalia-African Biodivers. Conserv. 2017, 47, 1-11. [CrossRef]

53. Baron, J. Biases in the Quantitative Measurement of Values for Public Decisions. Psychol. Bull. 1997, $122,72$. [CrossRef]

54. Churchill, T.N.; Bettoli, P.W.; Peterson, D.C.; Reeves, W.C.; Hodge, B. Angler conflicts in fisheries management: A case study of the striped bass controversy at Norris Reservoir, Tennessee. Fisheries 2002, 27, 10-19. [CrossRef]

55. Trainor, S.F. Realms of value: Conflicting Natural Resource Values and Incommensurability. Environ. Values 2006, 15, 3-29. [CrossRef] 
56. Kellert, S. A biocultural basis for an environmental ethic. In The coming transformation: Values to Sustain Human and Natural Communities; Kellert, S., Speth, J.G., Eds.; Yale School of Forestry \& Environmental Studies: New Haven, MA, USA, 2009; pp. 21-38.

57. Slovic, P. Perception of Risk. Science 1987, 236, 280-285. [CrossRef] [PubMed]

58. Slovic, P. Trust, emotion, sex, politics, and science: Surveying the risk-assessment battlefield. Risk Anal. 1999, 19, 689-701. [CrossRef] [PubMed]

59. Sellnow, T.L.; Littlefield, R.S.; Vidoloff, K.G.; Webb, E.M. The Interacting Arguments of Risk Communication in Response to Terrorist Hoaxes. Argum. Advocacy 2009, 45, 135-150. [CrossRef]

60. ICCAs. Available online: http://www.iccaregistry.org/en/about/iccas (accessed on 2 October 2017).

61. Chas-Amil, M.L.; Touza, J.; Prestemon, P. Spatial Distribution of Human-Caused Forest Fires in Galicia (NW Spain). Ecol. Environ. 2010, 137, 247-258. [CrossRef]

62. Valentine, G. Tell Me about... Using Interviews as a Research Methodology. In Methods in Human Geography. A Guide for Students Doing a Research Project; Flowerdew, R., Martin, D., Eds.; Pearson: Harlow, UK, 2005; pp. 110-127.

63. Cope, M. Coding Qualitative Data. In Qualitative Research Methods in Human Geography; Hay, I., Ed.; Oxford University Press: Oxford, UK, 2010; pp. 281-294.

64. Crang, M. Analysing qualitative materials, In Methods in Human Geography. A Guide for Students Doing a Research Project; Flowerdew, R., Martin, D., Eds.; Pearson: Harlow, UK, 2005; pp. 218-232.

65. Kearns, R. Undertaking Observational Research. In Qualitative Research Methods in Human Geography; Hay, I., Ed.; Oxford University Press: Oxford, UK, 2010; pp. 241-258.

(C) 2018 by the authors. Licensee MDPI, Basel, Switzerland. This article is an open access article distributed under the terms and conditions of the Creative Commons Attribution (CC BY) license (http:/ / creativecommons.org/licenses/by/4.0/). 